\title{
WAJAH PENDIDIKAN FORMAL DI TANAH LUWU PASCA PROKLAMASI (1945-1950)
}

\section{The Performance of Formal Education in Luwu Post Proclamation (1945-1950)}

\author{
Rismawidiawati \\ Balai Pelestarian Nilai Budaya Makassar \\ Jl. Sultan Alauddin-Tala Salapang Km 7, Makassar 90211 \\ Email: rismawidiawati@gmail.com
}

Naskah diterima tanggal 10 Februari 2015. Naskah direvisi tanggal 10 Maret 2015. Naskah disetujui tanggal 22 Mei 2015

\begin{abstract}
Abstrak
Wajah pendidikan formal di Tanah Luwu pasca proklamasi kemerdekaan Indonesia laksana bayi pendidikan yang baru belajar berjalan. Sehingga periode itu, dapat dikatakan sebagai pijakan dari perjalanan pendidikan pada daerah tersebut di masa kini. Sayangnya, informasi tentang upaya untuk mencerdaskan kehidupan bangsa masih sangat kurang, sehingga menjadi penting untuk menggambarkannya di tengah pasang surut dunia politik ketika itu. Dengan melakukan penelitian yang disajikan secara deskriptif analitis melalui 4 (empat) tahapan metode penelitian sejarah, yaitu; pengumpulan sumber (heuristic), kritik data atau sumber, interpretasi, dan historiografi. Selain itu, digunakan juga teknik pengumpulan data melalui wawancara. Hasil yang ditemukan menunjukkan, perjalanan pendidikan pasca proklamasi di daerah Luwu masih terseok-seok. Jumlah sekolah yang masih sedikit dibanding jumlah penduduk, tenaga pengajar yang kurang dan sebagian besar tampil memimpin pemuda pejuang yang aktif untuk mempertahankan proklamasi kemerdekaan, kurangnya kesadaran dan keinginan masyarakat untuk bersekolah akibat pemahaman tentang sekolah bentukan Belanda, serta situasi politik pada masa 1945-1950 menjadi faktor-faktor penyebab pendidikan di Luwu masih berjalan lamban. Gambaran ini diharapkan dapat memperkaya khasanah pengetahuan tentang pendidikan, dan dapat menjadi bahan studi untuk memajukan pendidikan di Tanah Luwu saat ini. Diharapkan juga berguna sebagai bahan pertimbangan kebijakan bahwa faktor lingkungan sangat berpengaruh terhadap kemajuan sebuah pendidikan.
\end{abstract}

Kata kunci: pendidikan, pasca proklamasi, Luwu, dan Belanda.

\begin{abstract}
The look of formal education in Luwu after the proclamation of Indonesian independence was like a baby learning to walk. Thus, the period could be said as the foothold of education expedition in the area nowadays. Unfortunately, the information about the efforts to educate this nation life was not widely spread. Therefore, it was important to describe the situations which were ups and downs in politics at that time. The research was conducted and presented in descriptively analytical through 4 (four) stages of historical research methods, namely the collection of source (heuristic), data critiques or source, interpretation, and historiography. In addition, the interviews were also employed to collect data. The results show that the education expedition in Luwu after the proclamation was still limp; the small number of schools compared to the total of population, the limited number of teachers, the appearance of young people as the leaders to actively defend the proclamation of independence, the lack of people's awareness and desire to attend school due to the understanding of the school formation of the Netherlands. Besides the political situation in the period 1945 - 1950 became the factors causing the education in Luwu still ran slowly. This picture is expected to enrich the knowledge repertoire of education nowadays, and it can become the study materials to promote education in Luwu. In addition, it is also expected to be the policy consideration that environmental factors highly influence the progress of education.
\end{abstract}

Keywords: education, after proclamation, Luwu, and the Netherlands. 


\section{PENDAHULUAN}

J ika bumi tempat berpijaknya pendidikan nasional bangsa Indonesia kini seringkali terlihat bergoyang, maka sistem pendidikan masih saja menyangsikan. Prosesnya menyulitkan tidak hanya siswa, tetapi juga guru dan orang tua, dan perilaku pelajar pun menjadi gamang. Maka, tengoklah bagaimana pendidikan formal itu tumbuh pertama kalinya di atas bumi tersebut. Barangkali di sana ada kecerdasan yang tertinggal dan tak terbawa ke depan pintu gerbang kebahagiaan bangsa. Barangkali saat ini kita perlu kembali melirik pemikiran cerdas Ki Hajar Dewantara atau kecerdasan tokoh-tokoh daerah seperti yang ada di Tanah Luwu.

Fakta sejarah telah memperlihatkan kepada kita bahwa kemerdekaan Indonesia dimulai secara nyata dari adanya kecerdasan dan kecerdasan itu dapat berfungsi setelah disentuh oleh pendidikan. Kita mestinya meyakini bahwa kecerdasan bangsa adalah aset utama bangsa untuk melestarikan bangsa itu sendiri. Apapun yang dimiliki oleh negara, baik itu kekayaan alam, sosial, budaya misalnya, tidak akan ada artinya jika pengelolaannya tidak dilandasi kecerdasan. Demikian pula, apa pun tujuan mulia bangsa ini, tidak akan tercapai tanpa adanya kecerdasan. Dan kecerdasan hanya akan tercapai dengan adanya pendidikan yang baik.

Tampaknya, hal ini pun diyakini oleh negara Indonesia. Pasca proklamasi, salah satu tujuan negara Republik Indonesia adalah mencerdaskan kehidupan bangsa. Hal ini dapat kita lihat jelas pada alinea ke-4 pembukaan UUD 1945 yang menyatakan ".............dan untuk memajukan kesejahteraan umum, mencerdaskan kehidupan bangsa, dan ikut melaksanakan ketertiban dunia yang berdasarkan kemerdekaan, perdamaian abadi dan keadilan sosial, maka.....", selanjutnya pada pasal 31 ayat (1) UUD 1945 menyatakan "Setiap warga negara berhak mendapat pendidikan"

Namun, kemerdekaan Indonesia yang sudah mencapai 69 (enam puluh sembilan) tahun tidak menjadikan Indonesia matang dalam dunia pendidikan. Dewasa ini, pendidikan masih menjadi problem tersendiri bagi pemerintah Indonesia. Beda pemerintah maka berbeda pula caranya dalam menerapkan sistem pendidikan di negara ini. Pemerintah masih saja mencari "wajah" pendidikan yang tepat bagi rakyatnya. Rasanya seperti mencari kecerdasan Ki Hajar Dewantara yang kini seolah hilang dalam perbincangan dunia pendidikan, dan rasanya seperti mencari kecerdasan tokoh-tokoh pendidikan lainnya yang telah menjadi penuntun jalannya pendidikan di seluruh wilayah Indonesia.

Sejalan dengan tujuan negara, pada konteks lokal Kota Palopo pun menempatkan pendidikan pada posisi yang utama. Walikota Palopo telah mencanangkan Palopo sebagai kota tujuan pendidikan. Bersamaan dengan cita-cita itu, dibentuklah Dewan Pendidikan Kota Palopo yang diharapkan dapat bekerja keras untuk mewujudkan cita-cita Palopo sebagai Kota Tujuan Pendidikan (Majalah Sahabat Kita, Edisi IV April 2014:22). Upaya ini tentulah tidak mudah di tengah tantangan di era modern ini yang begitu kompleks, dan semua upaya itu seharusnya disadari bahwa pijakannya berasal dari awal perjalanan pendidikan Indonesia di era pasca proklamasi. Tanpa itu, maka gambaran apa yang telah dicapai dan apa yang akan dicapai menjadi sebatas fatamorgana.

Di masa lalu, tantangan pendidikan tak kalah kompleksnya. Hal ini dikarenakan oleh kenyataan kompleksnya dimensi-dimensi eksternal pendidikan yang meliputi dimensi sosial, politik, ekonomi, dan budaya. Pasca Proklamasi, situasi politik di Tanah Luwu belumlah stabil. Perlawanan Semesta Rakyat Luwu pada 23 Januari 1946 yang dipimpin Datu Luwu, Andi Djemma, pemberontakan DI/TII yang dilakukan oleh Kahar Muzakkar dan pembentukan Negara Indonesia Timur mewarnai situasi pasca proklamasi di Tanah Luwu. Lalu, bagaimanakah sebenarnya wajah pendidikan formal di Tanah Luwu pasca proklamasi dalam rangka mencerdaskan kehidupan bangsa di tengah pasang surut dunia politik ketika itu. Untuk mendukung pokok persoalan tersebut, ada dua pertanyaan lanjutan yaitu: bagaimana pendidikan di Luwu pada awal abad XX dan bagaimana situasi politik di daerah Luwu pada tahun 1945 - 1950. Kedua pertanyaan lanjutan tersebut diarahkan untuk menjawab pokok persoalan.

Pada salah satu media elektronik, Menteri Pendidikan dan Kebudayaan RI periode 2014-2019, Anies Baswedan menyatakan pendidikan Indonesia saat ini berada dalam situasi "gawat darurat". Hal ini disampaikan ketika memimpin pertemuan dengan para kepala dinas pendidikan seluruh Indonesia pada 1 Desember 2014. Dia menuturkan sejumlah fakta yang menunjukkan bahwa pendidikan di Indonesia memang dalam keadaan terpuruk (Metro TV, 1 Desember 2014). Berdasar pada banyaknya persoalan pendidikan pada konteks kekinian tersebut, sehingga tulisan ini menarik untuk diulas. 
Seperti pidato Soekarno pada HUT Proklamasi 1966 yang mengatakan, bahwa janganlah melihat ke masa depan dengan mata buta! Masa yang lampau adalah berguna sekali untuk menjadi kaca benggala dari pada masa yang akan datang. Demikian pulalah, tulisan ini dibuat dengan harapan bahwa ulasan wajah pendidikan formal di Tanah Luwu pasca proklamasi dapat meningkatkan semangat para kawula muda untuk terus berjuang mencerdaskan kehidupan bangsa di tengah gempuran tantangan yang semakin kompleks.

Seperti pada tulisan sejarah pada umumnya, artikel ini dibatasi oleh skop temporal dan spasial demi membatasi tulisan ini nantinya agar terhindar dari perihal yang tidak ada relevansinya dengan permasalahan yang diteliti. Pemilihan tahun 1945 didasarkan pada lahirnya Undang-Undang Dasar (UUD) 1945 sebagai landasan konstitusi bagi negara Republik Indonesia yang merdeka. Di dalam UUD 1945 termaktub secara jelas baik pada pembukaannya maupun pada beberapa pasal di dalamnya bahwa tujuan negara Republik Indonesia adalah untuk mencerdaskan kehidupan bangsa. Walaupun proklamasi kemerdekaan Republik Indonesia telah diproklamirkan 17 Agustus 1945, namun perjuangan rakyat Indonesia belum usai. Belanda tetap saja tidak ingin mengakui kemerdekaan Indonesia dan masih ingin menguasai Indonesia. Pasca proklamasi 1945 adalah masa yang tidak bisa dikatakan ringan dalam upaya mempertahankan kemerdekaan.

Artikel ini dibatasi tahun 1950 dengan alasan bahwa pengakuan kedaulatan pada 27 desember 1949 menjadi akhir masa revolusi bersenjata di Indonesia dan secara de jure pihak Belanda telah mengakui kemerdekaan Indonesia dalam bentuk Republik Indonesia Serikat (RIS). Namun atas kesepakatan rakyat Indonesia pada 17 Agustus 1950, RIS dibubarkan dan dibentuk NKRI. Selanjutnya pada 28 September 1950, Indonesia diterima menjadi anggota PBB yang ke-60. Hal ini berarti bahwa kemerdekaan Indonesia secara resmi telah diakui oleh dunia internaisonal.

Sementara skop spasialnya adalah Belopa dan Palopo Kabupaten Luwu, Provinsi Sulawesi Selatan. Pemilihan lokasi tersebut didasarkan pada adanya data bahwa sampai tahun 1945 Pendidikan di daerah Luwu masih terbelakang di banding daerah-daerah lain. Hal ini "menggelitik" keinginan penulis untuk meneliti daerah tersebut sebagai akibat subjektifitas penulis yang berasal dari daerah Luwu.
Artikel ini menggunakan empat tahapan metode penulisan sejarah yaitu, pengumpulan sumber, kritik sumber, interpretasi dan historiografi. Pada tahapan pengumpulan sumber, penulis telah menelusuri beberapa perpustakaan di Makassar dan wilayah Palopo. Telah ditemukan beberapa tulisan terkait topik ini, walaupun tulisan tersebut merupakan bagian dari buku. Sumber Belanda tidak banyak membantu karena keterbatasan penulis terhadap bahasa. Untuk itu, penulis mencoba menyikapi kelemahan itu pada beberapa literatur yang mengutip sumber-sumber Belanda.

Selain itu, digunakan juga metode wawancara untuk menguatkan sumber yang diperoleh. Penulis telah melakukan wawancara terhadap 6 (enam) informan yang tersebar antara Belopa, Bua dan Palopo. Tanpa mengurangi obyektifitas penulis, ayah penulis juga dimasukkan sebagai informan dengan alasan memang layak dimasukkan ke dalam kategori informan untuk topik ini karena merupakan saksi peristiwa periode 1945-1950. Demi menguatkan analisis penulis, dilakukan wawancara mendalam dengan beberapa pakar sejarah yang faham tentang pendidikan pada periode ini.

Tulisan tentang pendidikan pasca proklamasi di Kabupaten Luwu ini masih sangat jarang. Sepanjang bacaan penulis hanya ada beberapa buku tentang pendidikan di Sulawesi Selatan. Buku tersebut adalah Sejarah Pendidikan Daerah Sulawesi Selatan (1980) oleh Sarita Pawiloy dkk, Sejarah Pendidikan di wilayah Majene 1900 - 1942 (2013) oleh Suriadi Mappangara, dkk, dan Perkembangan Pendidikan Kolonial di Makassar 1876 - 1942 (1997) oleh Sarkawi. Buku Sarita Pawiloy membahas sejarah pendidikan mulai dari pendidikan tradisional sampai dengan pendidikan pada awal proklamasi. Buku ini termasuk komprehensif tapi sebagaimana judulnya, tulisan ini tidak mengerucut pada sebuah daerah diSulawesi Selatan tetapi memuat pendidikan di Sulawesi Selatan secara umum. Berbeda dengan tulisan ini, melihat pendidikan di masa proklamasi kaitannya dengan kondisi politik saat itu. Tulisan Suriadi Mappangara hanya terfokus pada wilayah Majene dan tulisan Sarkawi tidak menyentuh pasca proklamasi.

\section{Tinjauan Pustaka}

Sebelum melangkah lebih jauh, dianggap perlu untuk menjelaskan secara kongkret, beberapa istilah penting yang menjadi kerangka kerja (frame work) bagi tulisan ini. Hal ini dilakukan agar tidak terjadi kerancuan dalam pemahaman 
dan pembahasan lebih lanjut. Hal yang dianggap perlu untuk dijelaskan adalah kata "pendidikan", dan "pendidikan formal".

Pendidikan pada hakekatnya adalah usaha sadar dan terencana untuk mewujudkan suasana belajar dan proses pembelajaran agar peserta didik secara aktif mengembangkan potensi dirinya untuk memiliki kekuatan spiritual keagamaan, pengendalian diri, kepribadian, kecerdasan, ahklak mulia, serta keterampilan yang diperlukan dirinya masyarakat, bangsa dan negara. Sedang, pendidikan formal merupakan pendidikan yang diselenggarakan di sekolah-sekolah pada umumnya. Jalur pendidikan ini mempunyai jenjang pendidikan yang jelas, mulai dari pendidikan dasar, pendidikan menengah, sampai pendidikan tinggi. Tanah Luwu adalah salah satu kabupaten di Provinsi Sulawesi Selatan. Di masa lalu, Luwu adalah salah satu kerajaan tertua dan terbesar di Sulawesi Selatan.

Tabel 1. Perbedaan antara pendidikan formal, pendidikan non formal, dan pendidikan informal.

\begin{tabular}{|c|c|c|}
\hline Pendidikan formal & Pendidikan non-formal & Pendidikan informal \\
\hline $\begin{array}{l}\text { Tempat pembelajaran di gedung } \\
\text { sekolah. } \\
\text {, Ada persyaratan khusus untuk menjadi } \\
\text { peserta didik. } \\
\text { > Kurikulumnya jelas. } \\
\text { > Materi pembelajaran bersifat akademis. } \\
\text { > Proses pendidikannya memakan waktu } \\
\text { yang lama } \\
\text { > Ada ujian formal } \\
\text { > Penyelenggara pendidikan adalah } \\
\text { pemerintah atau swasta. } \\
\text { Tenaga pengajar memiliki klasifikasi } \\
\text { tertentu. } \\
\text { > Diselenggarakan dengan administrasi } \\
\text { yang seragam }\end{array}$ & $\begin{array}{l}\text { Tempat pembelajarannya bisa di luar } \\
\text { gedung } \\
\text {, Kadang tidak ada persyaratan khusus. } \\
\text {, Umumnya tidak memiliki jenjang yang } \\
\text { jelas. } \\
\text {, Adanya program tertentu yang khusus } \\
\text { hendak ditangani. } \\
\text {, Bersifat praktis dan khusus. } \\
\text {, Pendidikannya berlangsung singkat } \\
\text {, Terkadang ada ujian } \\
\text {, Dapat dilakukan oleh pemerintah atau } \\
\text { swasta }\end{array}$ & $\begin{array}{l}\text {, Tempat pembelajaran bisa di mana saja. } \\
\text {, Tidak ada persyaratan } \\
\text {, Tidak berjenjang } \\
\text {, Tidak ada program yang direncanakan } \\
\text { secara formal } \\
\text {, Tidak ada materi tertentu yang harus } \\
\text { tersaji secara formal. } \\
\text {, Tidak ada ujian. } \\
\text {, Tidak ada lembaga sebagai } \\
\text { penyelenggara. }\end{array}$ \\
\hline
\end{tabular}

Berdasarkan teori penyelenggaraan pendidikan secara formal, paling tidak ada lima faktor pendidikan, yaitu: a) pendidik; b) peserta didik; c) tujuan pendidikan; d) alat-alat sarana pendidikan; e) lingkungan pendidikan (Abd. Rahman Getteng, 2005: 117). Kelima faktor ini dinilai sebagai faktor utama yang menjadi dasar penyeleggaraan pendidikan secara formal. Mengacu pada pendekatan tersebut tulisan tentang wajah pendidikan formal di Kabupaten Luwu pasca proklamasi ini dapat dilihat. Kelima aspek tersebut, dilihat sebagai satu kesatuan untuk mengukur wajah pendidikan di Tanah Luwu ketika itu.

\section{PEMBAHASAN}

\section{Pendidikan Awal Abad XX di Indonesia}

Perhatian pemerintah Hindia Belanda terhadap pendidikan formal di Indonesia dimulai ketika seorang praktisi hukum dan politik asal Belanda, Mr. van Deventer pada tahun 1899 menulis dalam majalah De Gids (Panduan), berjudul Een Eereschuld (hutang kehormatan) (Baudet, 1987: 16). Pengertian Eereschuld secara substasial adalah "Hutang yang demi kehormatan harus dibayar, walaupun tidak dapat dituntut di muka hakim". Tulisan itu berisi angka-angka konkret yang menjelaskan pada publik Belanda bagaimana mereka menjadi negara yang makmur dan aman (adanya kereta api, bendungan-bendungan) adalah hasil kolonialisasi yang datang dari daerah jajahan di Hindia Belanda (Indonesia), sementara Hindia Belanda saat itu miskin dan terbelakang. Jadi sudah sepantasnya kekayaan tersebut dikembalikan.

Perhatian Deventer tidak berhenti di situ. Ketika Deventer menjadi anggota Parlemen Belanda, ia menerima tugas dari menteri daerah jajahan Idenburg untuk menyusun sebuah laporan mengenai keadaan ekonomi rakyat pribumi di Jawa dan Madura. Dalam waktu satu tahun, Deventer berhasil menyelesaikan tugasnya (1904). Dengan terbuka Deventer mengungkapkan keadaan yang menyedihkan, kemudian dengan tegas mempersalahkan kebijakan pemerintah.

Buntut dari itu, muncullah kaum etis yang di pelopori oleh Pieter Brooshooft (seorang wartawan koran De Locomotief) dan Conrad Theodore van Deventer yang ternyata mampu membuka mata pemerintah kolonial untuk lebih memperhatikan 
nasib para pribumi yang terbelakang. Pada 17 September 1901, Ratu Wilhelmina yang baru naik tahta menegaskan dalam pidato pembukaan Parlemen Belanda, bahwa pemerintah Belanda mempunyai panggilan moral dan hutang budi (een eerschuld) terhadap bangsa pribumi di Hindia Belanda. Ratu Wilhelmina menuangkan panggilan moral tadi ke dalam kebijakan politik etis, yang terangkum dalam program Trias Politica (Nasution, 1983:15) yang meliputi :
1. Edukasi
$=$ pengajaran dan pendidikan
2. Irigasi
$=$ perairan dan bendungan untuk keperluan pertanian

3. Transmigrasi $=$ perpindahan penduduk

Kebijakan politik etis ini mendapat dukungan dari kalangan kapitalis dan industrialis Belanda, namun dukungan itu bukannya tanpa maksud. Pada dasarnya para kapitalis berkeinginan untuk memasarkan hasil industrinya sambil melakukan perbaikan ekonomi rakyat Indonesia. Kebijakan pertama dan kedua disalahgunakan oleh Pemerintah Belanda dengan membangun irigasi untuk perkebunan-perkebunan Belanda dan emigrasi dilakukan dengan memindahkan penduduk ke daerah perkebunan Belanda untuk dijadikan pekerja rodi. Hanya pendidikan yang memiliki arti bagi bangsa Indonesia walaupun implementasinya tidaklah dapat dikatakanjuga tanpa maksud apaapa.

Pada 1905, tahun pemilihan di Belanda, van Deventer dan kawan-kawannya menang dalam Parlemen Belanda, yang karena itu mereka menjadi pemeran utama dalam pembentukan kabinet. Seorang anggota partai Demokrat Liberal, D. Fock, menjadi Menteri Jajahan. Dia bersedia memajukan dan meluaskan pendidikan para pribumi. Usaha ini terdukung oleh saran dan konsep Snouck Hurgronje, seorang profesor indolog di Leiden (1906), yang menyarankan agar pemerintah kolonial Belanda memberikan pendidikan kepada elit pribumi dalam tradisi yang paling baik dari Barat yang nantinya diharapkan menjadi tokoh penting yang berpengaruh luas dalam masyarakat Indonesia (Nathan Cross, Academia.edu: 1-5, diunduh tanggal 1 Desember 2014)

Sesuai dengan semangat politik etis, pemerintah kolonial Belanda memperbanyak jumlah sekolah. Pengaruh politik etis dalam bidang pengajaran dan pendidikan sangat berperan penting dalam pengembangan dan perluasan dunia pendidikan dan pengajaran di Hindia Belanda.
Salah seorang dari kelompok etis yang sangat berjasa dalam bidang ini adalah Mr. J.H. Abendanon (18521925), Menteri Kebudayaan, Agama, dan Kerajinan selama lima tahun (1900-1905). Sejak tahun 1900 inilah berdiri sekolah-sekolah, baik untuk kaum priyayi maupun rakyat biasa yang hampir merata di daerah-daerah.

Pada tahun 1903 mulai didirikan sekolah rendah yang dinamakan Volk School (Sekolah Desa) dengan masa belajar 3 tahun yang kemudian dilanjutkan dengan program VervolgSchool (sekolah Lanjutan) dengan masa belajar selama 2 tahun. Pemulaan sekolah semacam ini lalu dilanjutkan untuk tahun-tahun berikutnya, misalnya Meer Uitgebreid Leger Onderwijs (MULO), yakni sebuah sekolah yang jenjangnya setingkat SMP pada zaman Belanda dan program Algemeene Middelbare School (AMS) yang jenjangnya setingkat dengan SMA.

Walaupun cukup baik tujuan didirikan bentuk-bentuk persekolahan di atas, namun dalam praktiknya, sekalipun tidak secara langsung, terdapat kecenderungan diskriminatif. Kecenderungan itu nampak dalam hal cara menyaring anak sekolah. Caranya ialah dengan memberlakukan biaya sekolah yang cukup mahal, dan juga sering diutamakan bagi keluarga yang memiliki keturunan darah biru (darah ningrat, darah keraton) atau dari kalangan para "priyayi" (pangreh praja atau pegawai dalam kantor pemerintah Belanda). Oleh karena itu, bagi kalangan masyarakat bawah, hanya dari anggota masyarakat yang mampu atau kaya saja yang dapat menyekolahkan anak-anaknya ke jenjang pendidikan yang cukup tinggi. Bagi anggota masyarakat yang kurang berpunya atau miskin terpaksa tidak dapat memasukkan anak-anaknya ke sekolah, atau paling tidak terpaksa mengambil alternatif lain, misalnya memasukkan anak-anaknya ke dalam pondok pesantren.

Satu hal yang tidak dapat dipungkiri adalah bahwa tujuan penyelenggaraan sekolah yang dilakukan Belanda di atas tidak murni hanya semata-mata untuk memberdayakan pendidikan masyarakat, melainkan justru untuk menghasilkan tenaga birokrat (sesuai dengan level pendidikannya) untuk dapat direkrut dalam jabatan-jabatan teknis di pemerintahan kolonial Belanda.

Sebagai contoh, sejak 1864 oleh Belanda telah diintroduksi sebuah program ujian yang disebut Klein Ambtenaars' Examen, yaitu sebuah program ujian pegawai rendah yang harus ditempuh agar seseorang dapat diangkat sebagai pegawai 
pemerintah. Oleh karena itu, nampak jelas bahwa program untuk menciptakan birokrat rendahan yang cukup menonjol, apalagi setelah pada tahun 1900 diperkenalkan sekolah Opleiding School voor Inlandsche Ambtenaren (OSVIA), yaitu sebuah sekolah yang dipersiapkan untuk menjadi pegawai pemerintah untuk kalangan pribumi. Dengan demikian terdapat kesan kuat bahwa kegiatan pendidikan adalah untuk kelancaran ekonomi dan politik Belanda.

Pelaksanaan politik etis bukannya tidak mendapat kritik. Kalangan Indo, yang secara sosial adalah warga kelas dua namun secara hukum termasuk orang Eropa merasa ditinggalkan. Di kalangan mereka terdapat ketidakpuasan karena pembangunan lembaga-lembaga pendidikan hanya ditujukan kepada kalangan pribumi (eksklusif). Akibatnya, orang-orang campuran tidak dapat masuk ke tempat itu, sementara pilihan bagi mereka untuk jenjang pendidikan lebih tinggi haruslah pergi ke Eropa, yang biayanya sangat mahal.

Tampaknya, perkembangan pendidikan di Pulau Jawa tidak diikuti oleh daerah luar Pulau Jawa. Perkembangan pendidikan di luar Pulau Jawa agak terlambat. Hal ini dikarenakan, pusat pemerintah kolonial Belanda pada saat itu berada di Pulau Jawa, sehingga pemerintah kurang memberi perhatian pada daerah luar. Selain itu, daerah luar Pulau Jawa relatif tidak stabil keamanannya.

Di Sulawesi Selatan, sekolah ala barat ada pada tahun 1876. Pada tahun ini didirikan kweeksschool oleh Benjamin Frederik Matthes. Oleh masyarakat setempat, sekolah itu disebut sekolah raja. Sekolah ini didirikan untuk penyediaan tenaga guru. Penamaan sekolah tersebut pun dimungkinkan untuk penghormatan terhadap guru, juga kemungkinan karena para raja ikut menyokong pembangunan sekolah tersebut. Murid-muridnya pun pada umumnya berasal dari keluarga raja. Matthes dibantu oleh La Mangewa dan seorang guru bahasa daerah yang bernama Daeng Manassa dalam mengajar di sekolah itu. Gubernur Selebes (Sulawesi), Tromp sekaligus menjadi Presiden van de Schoolcommissie (Pawiloy, 1980: 51).

Pada tahun 1880, Matthes kembali ke Belanda. Sekolah ini kemudian diambil alih oleh pemerintah Hindia Belanda, sedang Matthes sendiri fokus pada pengumpulan hasil kesusteraan lama setelah mendapat gelar doktor pada tanggal 28 Januari 1881 (Pawiloy, dkk, 1980: 52). Kweekschool yang tadinya untuk mendidik calon guru, sejak diambil alih oleh pemerintah Hindia Belanda juga sebagai tempat untuk mempersiapkan calon pamongpraja. Sejalan dengan politik etis yang didengungkan pemerintah Hindia Belanda, pada tahun 1904 didirikanlah sekolah kelas dua dengan nama Gouvernemen School kelas dua di Butung Weg (sekarang bernama Jalan Butung) dan juga di Jalan Amanagappa, dekat lapangan Karebosi. Pada tahun 1905, sekolah tersebut berubah nama menjadi Inlandsche School, yang oleh masyarakat dikenal sebagai sekolah melayu.

Pendidikan di Sulawesi Selatan kemudian seakan berjalan di tempat ketika perhatian pemerintah Hindia Belanda terpusat pada usaha menguasai Sulawesi Selatan. Pemerintah disibukkan dalam upaya penyerbuan ke beberapa kerajaan. Kerajaan Luwu sendiri dapat ditundukkan pada tahun 1906. Hanya terdapat satu sekolah yang didirikan baru pada 1906 yaitu Hollandsche Ambonsche School (HAS). Sekolah ini didirikan oleh pemerintah Hindia Belanda demi membalas jasa orang-orang Ambon yang bertugas menyerang para raja di daerah itu. Sekolah ini sangat diskriminatif karena yang bisa memasuki sekolah ini hanya anakanak bangsawan.

Pada 1907, Belanda dapat menguasai seluruh daerah Sulawesi Selatan. Dengan demikian pemerintah Belanda dapat mengatur pemerintahan dengan leluasa. Pendidikan pun mulai kembali diperhatikan. Hollandsce Ambonsche School kembali didirikan sehingga sekolah Ambon ini menjadi dua di tahun 1907. Untuk orang keturunan Tionghoa, pemerintah membangun Hollandsche Chinese School (HCS) di Jalan Timor (Timor Weg). Warga keturunan Tionghoa ini cepat mendapat perhatian pemerintah untuk mendapat pendidikan dengan pertimbangan mereka umumnya pedagang. Sebagai pedagang dibutuhkan keahlian membaca dan menghitung sehingga dengan alasan itulah perlu segera diberikan pendidikan.

Menurut data sampai dengan tahun 1910, Pemerintah Hindia Belanda hanya mengelola tingkat pendidikan formal yang dinamakan sekolah dasar. Ada dua jenis pendidikan dasar pada 19041910 yaitu Inlandsche School dan Volksschool. Di sekolah-sekolah itu anak dididik menjadi orang jajahan dan diajari berhitung, menulis dan membaca untuk dipersiapkan menjadi pegawai rendah pada administrasi kekuasaan Hindia Belanda. Jumlahnya dapat dilihat pada table 2 di bawah ini (Pawiloy, dkk, 1980: 57). 
Tabel 2. Inlandsche School dan Volkschool $1904-1910$

\begin{tabular}{ccc}
\hline $\begin{array}{c}\text { Nama Daerah } \\
\text { (Afdelingen) }\end{array}$ & $\begin{array}{c}\text { Inlandsche School } \\
\text { (Sekolah Melayu) }\end{array}$ & $\begin{array}{c}\text { Volksschool } \\
\text { (Sekolah Desa) }\end{array}$ \\
\hline Kota Makassar & 3 & 5 \\
Afd Makassar & 5 & 20 \\
Afd Pare-Pare & 5 & 20 \\
Afd Mandar & 3 & 10 \\
Afd Bonthain & 3 & 10 \\
Afd Bone & 5 & 20 \\
Afd Luwu & 3 & 10 \\
Jumlah & 27 & 95 \\
\hline
\end{tabular}

Ketersediaan sekolah yang sedikit ini tidak seimbang dengan jumlah penduduk pada waktu itu. Pada 1910, jumlah penduduk Sulawesi Selatan sekitar 2 juta jiwa. Namun demikian, murid yang masuk pada sekolah-sekolah tersebut tidak mencapai target (Pawiloy dkk, 1982:58). Anakanak yang masuk sekolah yang didirikan Belanda itu kebanyakan berasal dari anak-anak pegawai pemerintah, dari keluarga para pedagang besar dan dari keluarga bangsawan yang keterlibatannya dalam peperangan hanya sedikit; apalagi yang sama sekali tidak ikut, atau bahkan memihak Belanda (Idwar Anwar, 2005:323).

Hal ini dikarenakan situasi politik belum pulih benar akibat penaklukan yang dilakukan Belanda. Sampai tahun 1910 masih terdapat gerakan-gerakan perlawanan terhadap kehadiran Belanda. Selain itu, ada anggapan di kalangan masyarakat bahwa jika sekolah, nantinya akan dijadikan tentara Belanda. Hal ini tentu bertentangan dengan hati nurani masyarakat yang tidak ingin dijajah oleh bangsa Belanda. Bahkan lebih jauh, ada yang beranggapan, bahwa jika tamat nantinya akan dibawa ke negeri Belanda. Berbeda dengan saat ini bahwa ke luar negeri adalah impian setiap orang. Di masa itu, yang terbayang di benak para masyarakat adalah justru sebaliknya.

Pada 1911, di Makassar dibangun Holland Inlandsche School HIS. ${ }^{1}$ Pendirian sekolah ini merupakan kemajuan di bidang pendidikan ketika itu, karena di sekolah ini mulai diajarkan bahasa Belanda. Bahkan, bahasa asing ini dijadikan bahasa pengantar. Sekolah ini dipersiapkan untuk pendidikan lanjutan dan lama pendidikan adalah tujuh tahun. Selanjutnya, tahun 1912-1920 dibuka pula HIS di daerah Bulukumba, Bonthain, Watampone, Palopo dan Parepare. Keterbatasan

1 (Sekolah HIS ini didirikan di Jalan Sungai Tangka sekarang, sekitar 3 kilometer dari Benteng Ujung Pandang). sekolah HIS ini membuat orang-orang yang ingin melanjutkan sekolah ke HIS, namun tidak ada di daerahnya mendatangi HIS yang terdekat.

Tapi sekali lagi, HIS ini hanya untuk orangorang yang mampu. Biasanya anak kepala kampung atau anak pedagang besar yang mampu masuk sekolah di HIS. Lainnya mengirimkan anaknya ke sekolah desa. Itulah sekolah sebenarnya untuk rakyat kebanyakan waktu itu. Kebanyakan anak petani tidak menyekolahkan anaknya, karena kesibukan di sawah. Anak petani kecil sibuk belajar menggembala dan membantu ayahnya di sawah. Berbeda dengan anak perabot desa yang mempunyai waktu luang.

Pada 1920, di Makassar didirikan (MULO) Middedelbare Uitgebruik Lagere Schaa Onderwijs. Sekolah ini adalah sekolah lanjutan pertama yang langsung diawasi oleh Residen Sulawesi Selatan. Sangat khusus, karena di sini diajarkan empat bahasa asing yaitu, bahasa Belanda, Jerman, Inggris dan Perancis. MULO adalah lanjutan dari HIS. Lulusan MULO bisa melanjutkan ke Algemeenne Middelbare School (AMS) di Batavia. Tahun 1921, didirikan pula OSVIA. Tahun 1925, didirikan Normaal School (NS)

Skema jalur lanjutan sekolah:

- Murid yang asalnya rakyat biasa $\rightarrow$ Volkschool $\rightarrow$ Vervolgschool $\rightarrow$ Kweekschool dan Noormal School Murid yang asalnya anak bangsawan $\rightarrow$ HIS $\rightarrow$ HIK, OSVIA, MULO

Melihat skema di atas, diskriminasi ini terlihat sangat jelas. Pemerintah Belanda sengaja menerapkan sistem dualisme pendidikan dalam rangka memecah belah bangsa.

Perkembangan pendidikan di Sulawesi Selatan mulai membaik pada tahun 1925. Banyak Volk School yang didirikan di kampung-kampung dalam wilayah Kedatuan Luwu. Walaupun demikian, sekolah-sekolah ini mengalami kekurangan guru. Untuk mengatasi hal tersebut, Pemerintah Belanda menerima tamatan Inlandsche School sebagai guru magang. Selain mengajar, guru magang ini berhak memberi penilaian dan ikut serta merundingkan hal-hal yang berhubungan dengan proses belajar mengajar pada sekolah tempat dia mengajar (Anwar, 2005: 323).

Guru tetap atau Kepala Sekolah yang diwajibkan membimbing para guru magang ini. Akan tetapi karena kesibukan yang banyak, guru tetap dan Kepala Sekolah tidak lagi mempunyai waktu untuk membimbing. Kepala Sekolah juga harus membagi diri dengan mengajar karena keterbatasan guru. Keadaan ini membuat kualitas pendidikan pada saat itu tidak maksimal. Guru 
magang ini tidak memenuhi kriteria sebagai tenaga pengajar, hanya dipaksakan karena keterbatasan jumlah guru.

\section{Situasi Politik Pasca Proklamasi di Luwu}

Berita proklamasi 17 Agustus 1945 sampai juga ke daerah-daerah di luar Pulau Jawa. Hal ini tidak terlepas dari peran Pewarta Selebes yang menyiarkan berita melalui radio dan surat kabar ke seantero penjuru Sulawesi Selatan. Ketika mendengar berita ini, rakyat Sulawesi Selatan menyambutya dengan gegap gempita. Namun, di sisi lain ketika mereka tahu bahwa Belanda masih ingin berkuasa di negeri mereka, serentak saja menyulutkan semangat juang para pemuda di seluruh penjuru Sulawesi Selatan.

Rakyat Sulawesi Selatan kemudian melawan dengan cara gerilya dan membantuk laskar-laskar rakyat yang pada umumnya dipelopori oleh kaum raja di daerah setempat. Untuk menghadapi perlawanan rakyat Sulawesi Selatan, komandan pasukan sekututerpaksa melakukan tindakan preventif dengan jalan meningkatkan aksi kekerasan.

Di Palopo, terjadi insiden disebabkan oleh tindakan-tindakan pasukan NICA yang memasuki sebuah masjid di Kampung Bua dan mengobrak abrik isi masjid. Bahkan pasukan itu menginjakinjak Alquran yang terdapat di dalam masjid itu. Tindakan pasukan NICA itu menimbulkan kemarahan para raja, pemuka agama dan masyarakat Palopo yang mayoritas beragama Islam.

Atas insiden ini, Datu Andi Djemma yang didukung oleh pemuda-pemuda pejuang dan pemuka-pemuka ulama pada tanggal 21 Januari 1946 mengeluarkan ultimatum kepada komandan pasukan Australia dan pasukan-pasukannya di Palopo. Isi ultimatum itu agar dalam 2x24 jam memerintahkan pasukan-pasukan Belanda yang berpatroli di dalam maupun di luar kota untuk menghentikan operasinya dan masuk ke dalam tangsi masing-masing. Namun ultimatum ini tidak diindahkan oleh komandan pasukan Australia.

Mengetahui bahwa ultimatum ini tidak diindahkan, maka pada 23 Januari 1946 malam hari, dilaksanakan serangan terhadap pasukan Australia dan Belanda di kota Palopo. Tapi, apa daya pejuang Luwu kalah persenjataan. Akibatnya raja, para pejuang, dan rakyat di Kota Palopo harus mengungsi keluar. Secara berangsur Kota Palopo dapat diduduki (Patang, 1975: 222).

Belanda merasa posisinya semakin kuat. Belanda kemudian melakukan penangkapan terhadap beberapa pimpinan dan pejuang Republik. Datu Andi Djemma yang harus mengungsi ke daerah pedalaman kerajaannya dapat ditangkap pada tanggal 2 Juni 1946. Datu Andi Djemma beserta keluarganya dan beberapa orang pengikutnya tertangkap di tempat persembunyiannya di Desa Batu Pute.

Penangkapan terhadap Datu Andi Djemma tidak menyurutkan langkah para pejuang untuk mempertahankan kemerdekaan Republik Indonesia. Sejak awal perjuangan, para pejuang Sulawesi Selatan menyadari bahwa mereka kalah dari segi persenjataan dibanding pihak Belanda. Untuk itu, beberapa orang pimpinan perjuangan telah memikirkan untuk mencari bantuan di Jawa. Di Jawa sendiri, telah ada pemuda pejuang yang berasal dari Sulawesi Selatan. Termasuk Abdul Qahhar Mudzakkar, pemuda pejuang dari Tanah Luwu yang berjuang di Jakarta.

Abdul Qahhar Mudzakkar bersamasama dengan Saleh Lahade dan Andi Mattalatta kemudian mengusulkan dibentuk Tentara Republik Indonesia (TRI) Persiapan Sulawesi untuk diberangkatkan ke Sulawesi. Pasukan ekspedisi pertama dapat dipatahkan oleh Belanda namun pasukan selanjutnya berhasil sampai ke Sulawesi Selatan. Keberangkatan pasukan ekspedisi dari Jawa ke Sulawesi ini berlangsung dari Juni 1946-Maret 1947 (Gonggong, 2004: 180). Kedatangan pasukan ini tentu menambah kuat kelaskaran yang telah dibentuk di Sulawesi Selatan.

Usaha para pejuang mematahkan Belanda terus dilakukan. Kegiatan semakin memuncak untuk melakukan perlawanan dalam rangka mempertahankan kemerdekaan. Banyak organisasiorganisasi mulai bermunculan. Namun di pihak Belanda juga seakan tidak kalah gencar terus melakukan segala usaha untuk mengembalikan kekuasaannya. Peningkatan serangan fisik disertai strategi dan taktik politik terus dilakukan. Salah satu upaya pemerintah Hindia Belanda adalah memeceha negara kesatuan RI dengan cara membentuk negaranegara bagian. Negara Indonesia Timur (NIT) merupakan bagian dari rencana Belanda untuk memecah belah.

Negara Indonesia Timur adalah negara bagian Republik Indonesia Serikat (RIS) meliputi wilayah Sulawesi, Sunda Kecil (Bali dan Nusa Tenggara) dan Kepulauan Maluku, ibukotanya Singaraja. Negara ini dibentuk setelah dilaksanakan Konferensi Malino pada 16-22 Juli 1946 dan Konferensi Denpasar dari tanggal 7-24 Desember 1946 yang bertujuan untuk membahas gagasan berdirinya negara bagian tersendiri di wilayah Indonesia bagian timur oleh Belanda. Pada akhir Konferensi Denpasar 24 
Desember 1946, negara baru ini dinamakan Negara Timur Besar, namun kemudian diganti menjadi Negara Indonesia Timur pada tanggal 27 Desember 1946 (Hasan, 2010: 65-70).

Sebagian masyarakat tidak mendukung terbentuknya RIS (kelompok unitaris) dan sebagian lagi mendukung terbentuknya negara federal (kelompok federalis). Masyarakat Sulawesi Selatan umumnya masuk ke dalam kelompok unitaris yang menghendaki negara sesuai UUD 1945 dan cita-cita proklamasi 17 Agustus 1945. Kelompok federalis mulai melemah setelah Raymond Westerling membantai rakyat di Sulawesi Selatan. Pembantaian ini dikenal dengan korban 40.000 jiwa.

Menanggapi situasi politik yang ternyata tidak hanya terjadi di daerah Sulawesi Selatan, pada 8 Maret 1950 pemerintah RIS mengeluarkan UU darurat No.11 tahun 1950 tentang tata cara perubahan susunan kenegaraan RIS. Usaha untuk meredam kemerdekaan Indonesia dengan jalan kekerasan berakhir dengan kegagalan. Belanda mendapat kecaman keras dari dunia internasional. Belanda dan Indonesia kemudian mengadakan beberapa pertemuan untuk menyelesaikan masalah ini secara diplomasi, lewat perundingan Linggarjati, perjanjian Renville, perjanjian Roem-van Roijen, dan Konferensi Meja Bundar. Akhirnya Belanda terpaksa mengakui kedaulatan Indonesia.

1. Keradjaan Nederland menjerahkan kedaulatan atas Indonesia jang sepenuhnja kepada Republik Indonesia Serikat dengan tidak bersjarat lagi dan tidak dapat ditjabut, dan karena itu mengakui Republik Indonesia Serikat sebagai Negara yang merdeka dan berdaulat.

2. Republik Indonesia Serikat menerima kedaulatan itu atas dasar ketentuan-ketentuan pada Konstitusinja; rantjangan konstitusi telah dipermaklumkan kepada Keradjaan Nederland.

3. Kedaulatan akan diserahkan selambatlambatnja pada tanggal 30 Desember 1949

Rantjangan Piagam Penjerahan Kedaulatan

Setelah penyerahan kedaulatan hasil Konferensi Meja Bundar (KMB) situasi kemiliteran menjadi berubah dan inilah awal konflik yang menyebabkan Qahhar melawan Soekarno. Organisasi pimpinan militer dikuasai orang-orang bekas KNIL yaitu para militer didikan Belanda, Qahhar sebagai komandan tertinggi di Indonesia Timur yang membawai Kalimantan, Sulawesi, Bali dan Maluku merasa dilecehkan. Orang-orang KNIL menguasai seluruh pucuk pimpinan batalyon dari Sumatera hingga Jawa kecuali batalyon di Indonesia Timur yang dipimpin oleh Qahhar Mudzakkar.
Bencana pun datang dengan keluarnya keputusan dari pusat yang hanya mengizinkan serdadu berpendidikan militer yang boleh menjadi tentara republik Indonesia. Artinya, ribuan laskar Sulawesi Selatan anak buah Qahhar ditolak menjadi bagian dari tentara republik Indonesia. Qahhar marah di depan Alex Kawilarangdan dia meletakkan pangkat dan atribut militernya, dan sejak saat itu Qahhar dicap pemberontak. Mereka lupa tanpa pekikan "Allahu akbar" dari para mujahidin yang pernah tidak mengenyam pendidikan militer, perjuangan mempertahankan kemerdekaan sangatlah sulit dan Belanda dengan mudahnya mengontrol republik ini.

Sikap berani Qahhar Mudzakkar sudah nampak ketika dengan lantangnya memprotes kebijakan perundingan dengan Belanda, di salah satu bukunya Qahhar menulis "tindakan khianat golongan Soekarno menjalankan politik kompromi, mengadakan perundingan dengan pihak Belanda pada masa meluas dan memuncaknya semangat perlawanan rakyat di seluruh kepulauan Indonesia, yang dipatahkan sekaligus dengan perjanjian Linggarjati tahun 1947, Perjanjian Renville tahun 1948, yang pada akhirnya dihancurleburkan dengan Konferensi Meja Bundar (KMB) pada tahun 1949, yang menghasilkan pemberian kedaulatan hadiah Belanda dengan syarat "tanpa Irian Barat", yang mempunyai rentetan akibat-akibat buruk seperti yang kita lihat sekarang..." (Erli Aqamuz, 2001).

Pada bulan Mei 1949, terjadi perundingan antara RIS yang diwakili Bung Hatta dan RI diwakili A.Halim yang keduanya menjabat sebagai perdana menteri dan memutuskan untuk mengembalikan bentuk Negara Indonesia adalah kesatuan. Pengumuman kepada rakyat akan bentuk penghapusan RIS dan kembalinya NKRI yang sesuai dengan proklamasi 17 Agustus 1945 dibacakan pada peringatan kemerdekaan yaitu tanggal 17 Agustus 1950. Dengan disepakatinya RIS kembali ke NKRI, maka secara otomatis Indonesia menjadi negara kesatuan kembali.

\section{Pendidikan Pasca Proklamasi di Luwu}

Setelah proklamasi kemerdekaan Indonesia tanggal 17 Agustus 1945, perubahan-perubahan tidak hanya terjadi dalam bidang pemerintahan saja, tetapi juga dalam bidang pendidikan. Perubahan yang terjadi dalam bidang pendidikan merupakan perubahan yang bersifat mendasar, yaitu perubahan yang menyangkut penyesuaian kebijakan pendidikan dengan dasar dan cita-cita suatu bangsa yang merdeka dan negara yang merdeka. 
Untuk mengadakan penyesuaian dengan cita-cita bangsa yang merdeka maka pemerintah pada tahun 1946 yaitu masa Menteri PP dan K, Mr Soewandi Mangoensarkoro, membentuk Panitia Penyelidik Pendidikan dan Pengajaran yang diketuai oleh Ki Hajar Dewantara.

Tugas dari panitia ini adalah:

1. Merencanakan susunan baru dari tiap-tiap macam sekolah

2. Menetapkan bahan pengajaran dengan mempertimbangkan keperluan yang praktis dan jangan terlalu berat

3. Menyiapkan rencana pelajaran untuk tiap jenis sekolah termasuk fakultas

Salah satu hasil dari panitia tersebut adalah mengenai perumusan tujuan pendidikan. Tujuan pendidikan nasional pada masa tersebut penekanannya adalah pada penanaman semangat patriotisme dan peningkatan kesadaran nasional, sehingga dengan semangat itu kemerdekaan dapat dipertahankan dan diisi. Kementerian pendidikan, pengajaran dan kebudayaan Rapublik Indonesia dalam tahun 1946 mengeluarkan suatu pedoman bagi guru-guru yang memuat sifat-sifat kemanusiaan dan kewarganeraan sebagai dasar pengajaran dan pendidikan di negara Republik Indonesia yang pada dasarnya berintisarikan Pancasila.

Meskipun demikian, pendidikan tidak serta merta mengalami perubahan dan perkembangan sebagaimana cita-cita bangsa ketika mengalami kemerdekaan. Periode ini memang bisa disebut sebagai fase krisis dan transisi. Masih belum ada konsep dan pedoman yang disepakati untuk digunakan oleh murid-murid terlebih lagi guruguru dalam proses belajar mengajar. Ditambah lagi pasca proklamasi, situasi politik masih belumlah aman.

Di daerah Sulawesi Selatan pada masa pasca proklamasi kemerdekaan masih dalam keadaan panas. Pemuda pendukung kemerdekaan dan pemerintah RI di satu pihak dan sekutu yang diboncengi Belanda di pihak lain saling berhadaphadapan. Raja-raja terkemuka, seperti raja Luwu, Bone ikut berdiri di belakang proklamasi. Organisasi-organisasi pemuda pejuang banyak dibentuk untuk mempertahankan kemerdekaan. Keadaan pun menjadi sulit. Hal ini tentu saja menyebabkan pendidikan dan segala aktivitasnya terganggu. Sebagian besar guru-guru tampil memimpin pemuda pejuang. Hal ini menambah daftar panjang persoalan yang dihadapi pendidikan di daerah Sulawesi Selatan terkhusus di daerah Luwu.
Seperti diungkap pada pembahasan sebelumnya, perkembangan pendidikan di Sulawesi berjalan lambat. Hal ini pernah diungkapkan oleh Ida Anak Agung Gde Agung pada tahun 1946. Menurutnya dari delapan juta penduduk, hanya ada seorang sarjana muda. Selain itu, digambarkan pula oleh Ida Anak Agung Gde Agung bahwa pada tahun itu sekolah menengah saja tidak ada (Gonggong, 2004: 69).

Pasca-proklamasi kondisi sekolah-sekolah bentukan Belanda masihlah sama dengan masamasa sebelum kemerdekaan. Murid-murid masih belum mencapai target. Walaupun sebetulnya jumlah penduduk lebih banyak dibanding sekolah yang tersedia. Hal ini dimungkinkan karena guru sekolah-sekolah tersebut adalah kebanyakan orang Ambon, Manado, Belanda dan satu dua orang Jawa. Orang Bugis Makassar tidak terlalu respect dengan orang Ambon, Manado dan Belanda. Selain karena perbedaan agama, juga karena diketahui bahwa anggota KNIL kebanyakan dari daerah-daerah tersebut. Selain itu, bangsawan di daerah Sulawesi Selatan tidak banyak mempergunakan kesempatan untuk menuntut ilmu melalui pendidikan formal. Hal ini berbeda dengan kondisi daerah Jawa dimana pendidikan formal yang diselenggarakan oleh pemerintah Belanda dimanfaatkan secara baik oleh kaum bangsawan.

Awal-awal pasca-proklamasi, kaum bangsawan di Sulawesi Selatan kurang tertarik pada lembaga-lembaga pendidikan yang didirikan oleh pemerintah Belanda karena mereka beranggapan, bahwa mereka akan dijadikan budak yang mengabdi kepada Belanda jika mereka menuntut ilmu di situ (Mattulada, 1975:475). Adapun muridmurid sekolah pada masa itu, kebanyakan berasal dari to-maradeka. Sikap ini membuat lingkungan kerabat kaum bangsawan di Sulawesi Selatan tidak berpendidikan formal. Bahkan Raja Bone, Andi Mappanyukki dan Datu Luwu, Andi Djemma adalah raja-raja yang buta huruf latin (Gonggong, 2004: 81). Hal ini bertentangan dengan data yang menyatakan bahwa Datu Andi Djemma sempat mengenyam pendidikan di Inlandsche School (Patang, 1975: 214).

Berbeda di masa Datu Luwu Andi Djenning, perhatian istana terhadap pendidikan mulai berubah. Mulai banyak anak-anak kalangan bangsawan yang mengambil bagian dalam sistem pendidikan. Hal ini juga karena pendidikan kalangan bangsawan dengan rakyat pribumi kebanyakan terpisah.

Keadaan pendidikan bentukan pemerintah tidaklah mengalami perkembangan signifikan 
pada masa pemerintahan NIT. Walaupun banyak siswa dan guru ikut berperang melawan KNIL, namun proses belajar mengajar tetap berlangsung. Situasi politik pada masa itu menyita tenaga dan pikiran pemerintah NIT di bawah Soekawati. Usaha pemeliharaan dan melanjutkan yang ditinggalkan Belanda sebelum Jepang dianggap sudah memadai.

Pada masa NIT, pemerintah telah membentuk Kementerian Pengadjaran yang diletakkan di Makassar. NIT menaruh perhatian besar terhadap pendidikan. Demi menarik minat masyarakat pribumi bersekolah, Dr. HJ van Mook, perwakilan NICA dalam pidatonya menjanjikan perlunya pengembangan kebudayaan dan pendidikan. Bahkan dijanjikan pula pemberian beasiswa ke luar negeri (Pawiloy, 1980:111).

Namun janji van Mook ini dianggap angin lalu oleh masyarakat Luwu saat itu. Mereka tidak tertarik dengan iming-iming beasiswa ini. Perasaan tidak suka terhadap Belanda masih dirasa cukup kuat di kalangan masyarakat. Ditambah lagi, pelbagai tindakan dari Kementerian Pengadjaran NIT di Makassar yang masih menempatkan wilayah Indonesia Timur sebagai sebuah negara yang terpisah dari negara Republik. Pimpinan kementerian ini masih saja memperjuangkan sistem dengan model federal padahal rakyat pada umumnya ingin menyesuaikan dengan sistem yang berlaku di daerah republik (Mappangara, 2013: 69).

Sedangkan, Menteri Pendidikan Pengajaran dan Kebudayaan (PP dan K) Ki Hajar Dewantara membuat "instruksi umum" berisi seruan kepada para guru agar meninggalkan sistem pendidikan kolonial dan mengutamakan patriotisme. Isi "instruksi umum" tersebut adalah:

1. Pengibaran "Sang Merah Putih" setiap hari di halaman sekolah

2. Menyanyikan lagu kebangsaan Indonesia Raya

3. Menghentikan pengibaran bendera Jepang dan menghapus nyanyian Kimigayo (lagu kebangsaan Jepang)

4. Menghapuskan pelajaran bahasa Jepang, serta segala upacara yang berasal dari Pemerintahan Balatentara Jepang

5. Memberi semangat kebangsaan kepada semua murid.

Selain itu dibuat pula berbagai peraturan dalam kabinet-kabinet selanjutnya untuk mengubah sistem pendidikan dan pengajaran lama dengan sistem yang lebih demokratis. Diawali dengan Kongres Pendidikan maka Menteri PP dan K membentuk Komisi Pendidikan yang tugasnya membentuk Panitia Perancang RUU mengenai pendidikan dan pengajaran. Sejak 18 Agustus 1945 hingga RIS 27 Desember 1949, yang menjadi Undang-Undang Dasar adalah UUD 1945 dan sekaligus sebagai pedoman dalam penyelenggaraan pendidikan.

Pasca dicapnya Qahhar Mudzakkar sebagai pemberontak, dia bergerilya dengan menjadikan hutan sebagai markasnya. Selama di hutan melakukan perlawanan, Qahhar banyak mengislamkan masyarakat di sekitar pegunungan Latimojong yang saat itu masih banyak belum mengenal Islam. Satu sisi lagi bahwa selama di hutan Qahhar mewajibkan semua penduduk untuk bisa membaca latin dan Arab. Menurut informan, setiap hari mereka disekolahkan, anak-anak sampai orang tua diajar membaca dan berhitung. Qahhar paham betul arti sebuah pendidikan dan nilai spiritual. Bahkan sekolah yang ada di hutan dibuat semi permanen. Ruangan pun disediakan dari kelas 1 sampai kelas 6 (Rusli, wawancara 30 Juni 2014).

Tabel 3. Banyaknya Sekolah s.d Tahun 1950 di Sulawesi Selatan

\begin{tabular}{ccc}
\hline No & Jenis Sekolah & Jumlah \\
\hline 1 & Taman Kanak-Kanak & 1 \\
2 & SD 6 tahun & 186 \\
3 & SMP & 7 \\
4 & SMA & 2 \\
5 & SMEA & 4 \\
6 & SPG & 3 \\
7 & SKKA & 1 \\
8 & Sekolah Teknik & 1 \\
9 & SPSA & 1 \\
10 & SPMA & 1 \\
\hline Sumber: Mattulada, $1975: 477$ &
\end{tabular}

Sumber: Mattulada, 1975: 477

Walaupun jumlah sekolah yang tersedia sampai tahun 1950 telah meningkat, namun ini tidak berarti bahwa pendidikan di daerah Luwu sudah berjalan baik. Sampai tahun 1950, pendidikan di daerah Luwu masih terseok-seok. Hal ini dikarenakan jumlah dan kualitas guru yang kurang.

Hingga tahun 1950, sudah terdapat 186 sekolah dasar, pemerintah yang berusaha meningkatkan mutu pendidikan merasa perlu melakukan pengadaan tenaga pengajar. Prioritas pengadaan pertama adalah calon guru SD karena lembaga pendidikan itu merupakan dasar untuk melanjutkan pendidikan ke tingkat yang lebih tinggi.

Kebutuhan ini sudah sangat diperlukan sehingga untuk mengadakan dalam waktu cepat dilakukan pembukaan kursus guru. Langkah pertama adalah pembukan kursus-kursus 
pengajaran untuk kursus pengantar ke kewajiban belajar (KP KPKB) pada Desember 1950. Maksud pengadaannya adalah untuk menolong mengatasi kekurangan tenaga guru pada sekolah dasar. Di samping itu, dilakukan penempatan secara merata tamatan Normaal School pada sekolah-sekolah. Dari Minahasa, Manado dan juga Gorontalo didatangkan 45 orang guru tamatan Sekolah Guru B (Pawiloy, 1980:115). Untuk sementara persoalan guru dapat diatasi dengan langkah ini.

\section{PENUTUP}

Pada awal abad XX, pendidikan mulai digalakkan. Hal ini dikarenakan adanya politik etis sebagai politik "balas budi" yang digencarkan Belanda. Walaupun demikian, perhatian masyarakat pribumi terhadap pendidikan masih rendah. Selain itu, sistem pendidikan dualisme yang diterapkan Belanda membuat rakyat kebanyakan tidak dapat mengenyam pendidikan.

Periode 1945-1950 adalah periode yang dikategorikan sebagai revolusi fisik. Pada masa ini, di Tanah Luwu ada sejumlah peristiwa yang mempengaruhi pendidikan. Perlawanan semesta Rakyat Luwu yang dipimpin Andi Djemma pada 21 Januari 1946, kemudian pembentukan Negara Indonesia Timur juga pemberontakan Abdul Qahhar Mudzakkar mewarnai situasi politik di Tanah Luwu.

Pendidikan pasca proklamasi di daerah Luwu masih terseok-seok. Jumlah sekolah yang masih sedikit dibanding jumlah penduduk, tenaga pengajar yang kurang sebagai akibat sebagian besar guru-guru tampil memimpin pemuda pejuang yang aktif mempertahankan proklamasi kemerdekaan, kesadaran dan keinginan masyarakat untuk bersekolah serta situasi politik pada masa 1945 1950 menjadi faktor-faktor penyebab pendidikan di Luwu masih berjalan lamban.

\section{UCAPAN TERIMA KASIH}

Proses penelitian yang melahirkan artikel ini telah melibatkan banyak orang yang sangat membantu baik secara teknis maupun berupa data. Karena itu, secara khusus saya sampaikan terima kasih kepada Ibu Dra. Lindyastuti Setiawati, MM. Kepala Balai Pelestarian Nilai Budaya (BPNB) Makassar yang telah memprogramkan tema penelitian ini sebagai kegiatan kantor dan menugaskan saya untuk melaksanakannya, dan terima kasih tak terhigga saya sampaikan kepada para informan di Kota Palopo; Hj. Arifah, Dr.
Muhaimin, Anas Sioja, Rusli Dayyang, Drs. Makmur Samas, dan Drs. Andi Sanad Kaddiraja.

\section{DAFTAR PUSTAKA}

Anwar, Idwar. 2005. Ensiklopedi Sejarah Luwu. Palopo: Komunitas kampong Sawerigading (Kampus) bekerjasama dengan pemerintah kota Palopo, Pemerintah Kabupaten Luwu, Pemerintah Kabupaten Luwu Utara dan pemerintah Kabupaten Luwu Timur.

Baudet, I.J Brugmans. 1987. Politik Etis dan Revolusi kemerdekaan. Jakarta : Obor.

Getteng, Abd. Rahman. 2005. Pendidikan Islam di Sulawesi Selatan (Tinjauan Historis dari Tradisional hingga Modern). Yogyakarta: Penerbit Grha Guru.

Gonggong, Anhar. 2004. Abdul Qahhar Mudzakkar: Dari Patriot Hingga Pemberontak. Yogyakarta: Penerbit Ombak.

Hasan, Sabriah. 2010. Andi Makkasau: Menakar Harga 40.000 Jiwa. Yogyakarta: Penerbit Ombak.

Majalah Sahabat Kita Edisi IV April 2014. Palopo: Pemerintah Kota Palopo.

Mappangara, Suriadi, dkk. 2013. Sejarah Pendidikan di Wilayah Majene 1900 - 1942. Makassar : BPNB Makassar (tidak terbit).

Mattulada, 1975. Latoa: Satu Lukisan Analitis terhadap Antropologi Politik Orang Bugis. Disertasi Doktor - Universitas Indonesia.

Memorie van Overgave F.C Vorstman 1924. Residen Celebes (terjemahan).

Nathan Cross - Politik Etis. www.academia.edu. diunduh tanggal 1 Desember 2014.

Nasution. 1983. Sejarah Pendidikan Indonesia. Bandung: Bumi Aksara

Patang, Lahadji. 1975. Sulawesi dan PahlawanPahlawannya. Jakarta: Yayasan Kesejahteraan Generasi Muda Indonesia.

Pawiloy, Sarita dkk. 1980. Sejarah Pendidikan Daerah Sulawesi Selatan. Ujung Pandang: Proyek Inventarisasi dan Dokumentasi Kebudayaan Daerah Departemen Pendidikan dan Kebudayaan.

Erli Aqamuz (Siti Maesaroh), 2001. Profil Abdul Qahhar Mudzakkar : Patriot Pejuang Kemerdekaan Republik Indonesia dan Syahid NII/TII. Rotterdam-Holland: Yayasan AlAbrar. https://serbasejarah.wordpress.com/ 2010/08/27/abdul-qahhar-mudzakkarsang-patriot-pejuang-islam-bag-2/ diunduh tanggal 03 Maret 2014. 